ORIGINAL ARTICLE

\title{
Multiple matings modify the estrous length, the moment of ovulation, and the estradiol and LH patterns in ewes
}

\author{
Juan Pedro Bottino ${ }^{*}$ (D), Raquel Pérez-Clariget ${ }^{2}$ (D), Mariana Garcia Kako Rodriguez ${ }^{3}$ (D), Marcelo Ratto ${ }^{4}$ (D), \\ Rodolfo Ungerfeld ${ }^{\mathbf{1}}$ (D) \\ 'Departamento de Biociencias Veterinarias, Facultad de Veterinaria, Universidad de la República, Montevideo, Montevideo, \\ Uruguay \\ ${ }^{2}$ Departamento de Producción Animal y Pasturas, Facultad de Agronomía, Universidad de la República, Montevideo, \\ Montevideo, Uruguay \\ ${ }^{3}$ Departamento de Medicina Veterinária Preventiva e Reprodução Animal, Faculdade de Ciências Agrárias e Veterinárias, \\ Universidade Estadual Paulista "Júlio de Mesquita Filho", Jaboticabal, São Paulo, Brasil \\ ${ }^{4}$ Instituto de Ciencia Animal, Facultad de Ciencias Veterinarias, Universidad Austral de Chile, Valdivia, Valdivia, Chile
}

How to cite: Bottino JP, Pérez-Clariget R, Rodriguez MGK, Ratto M, Ungerfeld R. Multiple matings modify the estrous length, the moment of ovulation, and the estradiol and LH patterns in ewes. Anim Reprod. 2021;18(3):e20210045. https://doi.org/10.1590/1984-3143-AR2021-0045

\begin{abstract}
In several species, mating reduces the estrous length and advances ovulation. The aim of this study was to determine if multiple matings reduces the estrous length and modifies the moment of ovulation, as well as the estradiol and LH patterns in ewes. The estrous cycle of Corriedale ewes was synchronized, and the onset of receptivity was monitored every $3 \mathrm{~h}$ with rams, avoiding mating. At the estrous onset, ewes were assigned to two experimental groups ( $n=10$ each): 1 ) estrous was monitored every $3 \mathrm{~h}$ with a ram avoiding mating (group CON), and 2) a ram was allowed to mate and ejaculate once every $3 \mathrm{~h}$ (group MAT). The ovaries were scanned with transrectal ultrasonography and blood samples were collected for measuring $17 \beta$-estradiol and LH concentrations every $3 \mathrm{~h}$ until ovulation. Estrus was shorter in MAT than CON ewes ( $24.7 \pm 1.5$ h vs. $30.4 \pm 1.5$ h, respectively; $P=0.02$ ); the proportion of animals that ovulated

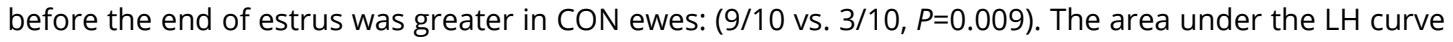
(AUC) was greater in MAT than CON ewes (36.1 $\left.\pm 3.5 \mathrm{ng} \cdot \mathrm{h}^{-1} \cdot \mathrm{mL}^{-1} \mathrm{vs} 24.9 \pm 3.5 \mathrm{ng} \cdot \mathrm{h}^{-1} \cdot \mathrm{mL}^{-1} P=0.03\right)$. However, MAT ewes had a lower 17ß-estradiol AUC than CON ewes $\left(41.0 \pm 4.9 \mathrm{pg} \cdot \mathrm{h}^{-1} \cdot \mathrm{mL}^{-1} \mathrm{vs} 59.4 \pm 4.9 \mathrm{pg} \cdot \mathrm{h}^{-1} \cdot \mathrm{mL}^{-1}\right.$ $P=0.01$ ). Mating reduced the estrous length, induced a greater secretion of $\mathrm{LH}$ but less total $17 \beta$-estradiol secreted and, additionally, ovulation occurred more frequently after the end of estrus in mated ewes.
\end{abstract}

Keywords: copula; estrous cycle; follicle; preovulatory LH surge; sexual behavior.

\section{Introduction}

Mating reduces the estrous length and may advance ovulation in several ruminants. As early as 1950, Marion et al. (1950) reported that ovulation occurred earlier in cows that were mated (penetration and ejaculation) during the first 6-8 hours of behavioral estrus than nonmated animals. This is explained by the advancement of the preovulatory discharge of $\mathrm{LH}$, and thus the moment of ovulation by cervical stimulation and mating (Randel et al., 1973). Estrous length is also shorter in does mated by vasectomized bucks than in non-mated females (Romano and Abella, 1997; Romano et al., 2016), regardless of the number of matings (Romano, 1994a). Mating and insemination also shorten the time between the onset of estrus and ovulation in pigs (Signoret et al., 1972; Waberski et al., 1995).

* Corresponding author: jpedrobgvet@gmail.com

Received: May 31, 2021. Accepted: August 12, 2021

Financial support: None.

Conflicts of interest: The authors have no conflict of interest to declare.

(c) (i) Copyright (c) The Author(s). This is an Open Access article distributed under the terms of the Creative Commons Attribution License, which permits unrestricted use, distribution, and reproduction in any medium, provided the original work is properly cited. 
The mechanism by which mating reduces the estrous length and hastens ovulation is still controversial. On one hand, the physical contact of the penis against the vaginal fornix was proposed as the main stimulus in goats (Romano, 1994b; Romano and Benech, 1996), but in camelids, including the llama, a factor present in the male's seminal plasma, called beta nerve growth factor ( $\beta N G F$ ) induces the LH peak (Ratto et. al., 2012).

In ewes, there is a paucity of information on the possible effects of mating on the dynamics of the estrous period. If ewes remain in continuous physical contact with rams, estrous length is reduced (Fletcher and Lindsay, 1971) and the LH surge and ovulation advanced (Lindsay et al., 1975) compared to ewes isolated from males. However, in those studies ewes were also treated with equine Chorionic Gonadotrophin (eCG), so it is not possible to know the effects of mating in natural estrus. Moreover, as the number of matings is extremely uneven among different ewes (Tilbrook and Cameron, 1990), it is possible that while some ewes have been mated several times, while others may have remained unmated in those earlier studies.

The hypothesis of this study was that multiple matings, including penetration and ejaculation, shortens estrous length, advances ovulation, and modifies the $17 \beta$-estradiol and LH patterns in ewes. Therefore, the objectives were to compare the estrous length, LH and $17 \beta$-estradiol patterns, and the moment of ovulation in mated and unmated estrous ewes.

\section{Methods}

\section{Animals and general management}

The experiment was performed at the Estación Experimental "Bernardo Rosengurt" from the Facultad de Agronomía, Universidad de la República (Cerro Largo, Uruguay, $32^{\circ}$ S), during the breeding season (March, autumn in the south hemisphere). The experimental protocol was approved by the Comisión de Ética en el Uso de Animales (CEUA) of the Universidad de la República (UdelaR). Initially, the estrous cycle of 30 multiparous Corriedale ewes was synchronized to ensure the availability of 20 ewes finally included in the study (4 to 6 years old, $51.9 \pm 2.2 \mathrm{~kg}$, mean \pm SEM). A clinical and gynecological examination and transrectal ultrasonography were performed using a 7.5 MHz linear array transducer coupled to an IUStar monitor (United Imaging, IUStar 160 Vet model, Beijing, China) to determine health and reproductive status 21 days before beginning the study. Ewes continued to graze natural pastures and received rice bran (300 g.animal ${ }^{-1}$.day ${ }^{-1}$ ) during the period of the study. Four Corriedale rams ( $4-6$ years old, $49.8 \pm 3.3 \mathrm{~kg}$ ) were also used in the study. The rams were all sexually experienced and were andrological examined one month before beginning the study.

To reduce the number of animals that were examined simultaneously, the study included two replications (15 ewes initially synchronized in each), beginning the treatments with 5 days of separation between replications. Estrous cycles of all ewes were synchronized using two doses of a PGF-alpha analogue (cloprostenol sodium; $2.53 \mu \mathrm{g} / \mathrm{kg}$; Ciclase DL, Zoetis, Buenos Aires, Argentina) 14 days apart. Estrous onset was checked in small pens every $3 \mathrm{~h}$ beginning $24 \mathrm{~h}$ after the second dose, introducing a tethered ram. The ram was allowed to mount the ewes taking extreme care to prevent mating (penis penetration), withdrawing the ram when ewe receptivity was confirmed (when the female remained immobile accepting the mount of the male). In each detection in which there were two or an even number of ewes in estrus, one of them was randomly assigned to one of two experimental groups. In one group, ewes' receptivity was monitored with the same system every $3 \mathrm{~h}$, determining if the ewe was still in estrus, but preventing mating (group CON, $n=10,5$ in each replication, 0 matings). The ewes of the other group were mated once with a ram in each detection, every $3 \mathrm{~h}$, confirming the ejaculation observing the intensive perineal contractions and the postejaculatory immobilization (group MAT, $n=10,5$ in each replication, $6.4 \pm 0.5$ matings, mean \pm SEM). The detection of estrous receptivity continued for each ewe every $3 \mathrm{~h}$ until the ewe was not receptive to further mounting. The rams were changed in every detection and each group using the four rams in both groups. 


\section{Ovarian ultrasound examination}

After confirming the receptivity and before allocating each ewe to an experimental group, ovaries were examined by transrectal ultrasound using a 7.5 MHZ linear transducer (United Imaging, IUStar 160 Vet model, Beijing, China), determining the size of the preovulatory follicle every $3 \mathrm{~h}$. Briefly, the animal remained in a standing position, inserting the probe, previously lubricated with carboxymethyl cellulose gel, into the rectum. After locating the uterus, both ovaries were searched for and located, and the diameters of all the follicles greater than $3 \mathrm{~mm}$ were measured. Two diameters were measured for each follicle, and the average was calculated. These follicles were measured again in the subsequent moment of estrus detections to determine their regression or ovulation. Only follicles that exceeded $5 \mathrm{~mm}$ were considered as possible ovulatory follicles, and ovulation was considered when a follicle greater than $5 \mathrm{~mm}$ disappeared. Ultrasounds were performed every $3 \mathrm{~h}$ from the time the estrous was detected until $3 \mathrm{~h}$ after ovulation.

\section{Collection of blood samples, and measurement of $17 \beta$-estradiol and LH concentrations}

After the ultrasound scanning, blood was collected by jugular venipuncture to determine estradiol and LH concentrations. Samples were placed in dry tubes without anti-coagulants, centrifuged at $3000 \mathrm{rpm}$ for $15 \mathrm{~min}$, and serum was separated and stored at $-20{ }^{\circ} \mathrm{C}$ until hormonal measurements were performed. Serum LH concentrations were measured using a double-antibody liquid phase radioimmunoassay with ovine LH radioiodinated (LER 1374-A), ovine antibodies CSU-204 and standard ovine LH oLH-S25 (provided by NIADDK, USA) in $200 \mu \mathrm{L}$ in duplicate, according to the procedure described by Recabarren et al. (1996). The mean intraassay coefficient of variation was $3.6 \%$ and the minimum detectable limit of the assay was $0.10 \mathrm{ng} / \mathrm{mL}$. Serum $17 \beta$-estradiol concentration was determined using a commercial liquid phase kit DIAsource E2-RIA-CT (DIAsourcelnmunoAssays S.A., Louvain-la-Neuve, Belgium). The mean intraassay coefficient of variation was $5.5 \%$ and the minimum detectable limit of the assay was $0.01 \mathrm{pg} / \mathrm{mL}$.

\section{Definitions and statistical analysis}

The onset of estrus was considered the mean time between the last time than an ewe did not stand to be mounted by the ram and the first time it was receptive to the ram (Ungerfeld and Rubianes, 1999). Similarly, the end of the estrus was defined as the mean time between the last time that the ewe stands to be mounted and the first in which was not receptive to the ram. The estrous length was considered the time elapsed between the onset and the end of estrus. The time of ovulation was considered the midpoint between the last moment that the preovulatory follicle was observed and the time in which it was not observed again (Roelofs et al., 2004).

The onset of the $\mathrm{LH}$ peak was considered as the first value greater than $3 \mathrm{ng} / \mathrm{mL}$ and the peak was defined as when concentration reached maximum values (Romano et al., 2018). The area under the curve (AUC) of LH and 17ß-estradiol were calculated using the GraphPadPrism Demo (GraphPad Software Inc., San Diego, USA). Duration of the LH peak was defined as the time interval from the onset of the LH surge until it returned to the baseline concentration (time interval when values were $3 \mathrm{ng} / \mathrm{mL}$ or less).

Estrous length, LH peak duration, intervals from the onset of estrus to ovulation, from the end of estrus to ovulation, from the onset of estrus to the onset of the LH peak, from the onset of the LH peak to the end of estrus, from the onset of LH peak to ovulation, the AUC of LH and $17 \beta$-estradiol, and the LH AUC/17 $\beta$-estradiol AUC ratio, were compared using a mixed model (SAS University Edition). The model included the treatment as the fixed effect and the replication as a random effect. The frequency of ewes having ovulations before or after the end of estrus was compared with Fisher's exact probability test. The differences were considered statistically significant when $P \leq 0.05$, and as tendencies when $0.1 \leq P<0.05$. 


\section{Results}

In ewes of the MAT group, there was a shorter duration of behavioral estrus $(P=0.02)$, and the moment of ovulation in relation to the end of estrus was modified ( $P=0.03$ ) (Table 1). Only single ovulations were detected. The proportion of animals having ovulations before the end of estrus was greater in CON than MAT ewes ( $9 / 10$ vs $3 / 10$, respectively; $P=0.009$ ). The intervals from the onset of estrus to ovulation, onset of estrus to onset of the LH peak, the onset of the $\mathrm{LH}$ peak to end of estrus, and the onset of the LH peak to ovulation, as well as the LH peak duration, did not differ between groups (Table 1). The LH AUC was greater in ewes of the MAT than CON ewes $(P=0.03)$, but the $17 \beta$-estradiol AUC was greater in ewes of the CON than MAT ewes $(P=0.01)$ (Table 2$)$. The relationship $L H / 17 \beta$-estradiol ratio was greater in ewes of the MAT than CON group $(P=0.04)$.

Table 1. LSmeans, pooled SEM, and $P$ value of different reproductive variables and intervals recorded during the estrous detection period in control (CON) and mated (MAT) ewes. Estrus was monitored every $3 \mathrm{~h}$, with a ram that was allowed to mount but preventing penis penetration in CON ewes $(n=10)$, or ewes were allowed to mate with a ram with there being a vaginal penetration and ejaculation in MAT ewes $(n=10)$.

\begin{tabular}{lcccc} 
& CON & MAT & Pooled SEM & $\boldsymbol{P}$ \\
Estrous duration $(\mathrm{h})$ & 30.4 & 24.7 & 1.5 & 0.02 \\
\hline LH peak duration $(\mathrm{h})$ & 8.9 & 9.0 & 1.4 & $\mathrm{~ns}$ \\
\hline Intervals & & & & \\
\hline Onset of estrous to ovulation $(\mathrm{h})$ & 25.8 & 26.8 & 1.6 & $\mathrm{~ns}$ \\
\hline End of estrous to ovulation $(\mathrm{h})$ & -4.6 & 2.1 & 2.0 & 0.03 \\
\hline Onset of estrous to LH peak $(\mathrm{h})$ & 1.5 & 3.5 & 2.3 & $\mathrm{~ns}$ \\
\hline LH peak to end of estrous $(\mathrm{h})$ & 22.8 & 16.6 & 2.3 & $\mathrm{~ns}$ \\
\hline LH peak to ovulation $(\mathrm{h})$ & 19.4 & 18.7 & 2.1 & $\mathrm{~ns}$ \\
\hline
\end{tabular}

Table 2. LSmeans, pooled SEM and $P$ value of area under the curve (AUC) of LH and 17ß-estradiol (E2) and $\mathrm{LH} / \mathrm{E} 2$ ratio in control (CON, $n=10)$ and mating (MAT, $n=10)$ groups during the estrous detection period. In CON group the estrous was monitored, every $3 \mathrm{~h}$, with a ram that was allowed to mount but preventing penis penetration while in the ewes of the MAT group estrous was monitored, every $3 \mathrm{~h}$, with ram was allowed to mount with penetration and ejaculation occurring.

\begin{tabular}{lcccc} 
& CON & MAT & Pooled SEM & $\boldsymbol{P}$ \\
AUC LH (ng.h-1.mL-1) & 24.9 & 36.1 & 3.5 & 0.03 \\
\hline AUC E2 $\left(\mathrm{pg} \cdot \mathrm{h}^{-1} . \mathrm{mL}^{-1}\right)$ & 59.4 & 41.0 & 4.9 & 0.01 \\
\hline LH/E2 (ng/pg) & 0.5 & 0.9 & 0.1 & 0.04 \\
\hline
\end{tabular}

\section{Discussion}

Multiple matings during the period of sexual receptiveness reduced the length of receptiveness, increased the secretion of $\mathrm{LH}$, increases the LH/E2 ratio, and modified the moment of ovulation in relation to the end of estrus in this study. It is interesting that those differences were observed although unmated ewes were located close to the rams, which also aimed to mate them. In this sense, in goats (Romano et al., 2016; Romano et al., 2018), the presence of the bucks itself modifies the estrous response in unmated females. Therefore, the differences could have been even greater if unmated ewes remained isolated from rams, reinforcing the concept of the high impact that contact with males has in the endocrine and ovarian patterns of the follicular phase. In any case, these results might have important practical implications in programs of artificial insemination (Al) as if ewes in estrus are identified with vasectomized rams, castrated androgen-treated males (wethers treated with testosterone) (Fulkerson et al., 1981), or androgenized ewes (Clarke, 1979), the stimulus, and thus, the moment of ovulation might differ.

Mating shortened the estrous length without modifying the time from estrous onset to ovulation but determining that most mated ewes ovulated after the end of the estrus. There 
are several possible non-opposed explanations for this effect. First, the vaginal-cervical stimulation induces the secretion of oxytocin (Kendrick et al., 1986), a hormone that suppresses ewes' receptiveness when infused in the ventromedial nucleus (Kendrick et al., 1993). Mated ewes also secreted more LH, and Wheeler et al. (1975) observed that progesterone concentration increases in coincidence with the LH surge, even before ovulation. As progesterone inhibits the secretion of GnRH in ewes (Goodman et al., 2002), which is the main hormone involved in maintaining the receptiveness in ewes (Caraty et al., 2002), this could also explain the advancement of the end of estrus. To confirm this explanation, it would be necessary to determine if the preovulatory concentration of LH modifies the pattern of progesterone increase during that period.

The lower total amount of $17 \beta$-estradiol secreted during this period in MAT ewes did not negatively affect the LH secretion, so there may be other mechanisms stimulating the LH discharge. First, mating may directly stimulate LH secretion by an independent pathway from that of $17 \beta$-estradiol action. The seminal plasma of rams also contains $\beta$-NGF (Harper et al., 1982; Druart et al., 2013), a protein that induces ovulation in llamas (Ratto et al., 2012; Kershaw-Young et al., 2012). Thus, the physical stimulus and/or the content of $\beta$-NGF or other molecules contained in the seminal plasma may directly stimulate the GnRH-LH secretion. It is also possible that the oxytocin released as a consequence of mating (Kendrick et al., 1986) stimulate directly the pituitary release of $\mathrm{LH}$, as happens in the marmoset (O'Byrne et al., 1990), rats, humans, and dogs (Shibusawa et al., 1955), and horses (Alexander et al., 1995). In any case, it is clear that mating induced the secretion of LH by a pathway independent of $17 \beta-$ estradiol secretion, opening interesting possibilities to study deeply alternatives to handle the moment of ovulation in ewes.

The shortening of the period of behavioral estrus induced by repeated matings may have important implications in the sexual selection process. In polyandric species as sheep, rams compete for access to estrous females (Preston et al., 2001; Ungerfeld and Lacuesta, 2015). However, in competitive breedings, even in wild conditions or in farmed animals, the final individual progeny produced by different rams is influenced by their social behavior, but also by the direct impact of its mating dynamics. For example, the second ram that mates an ewe eliminates an important volume of semen ejaculated by the first ram from the vagina of the ewe (Tilbrook and Pearce, 1986). In promiscuous species there is also sperm competition after semen deposition, reducing the probability of sperm deposited as a result of a specific mating being involved in fertilization (Parker and Birkhead, 2013). Thus, as different rams consistently prefer to mate with the same ewes (Tilbrook and Lindsay, 1987), and mate her repeatedly, the receptive period is shorten reducing the probability of being impregnated by another ram.

\section{Conclusion}

Overall, it was concluded that multiple matings reduce the length of behavioral estrus and modify the moment of ovulation in relation to the end of estrus. Furthermore, it induced a greater secretion of LH even when the ewe had relatively lesser estradiol concentrations. Thus, frequent mating greatly affects the endocrine pattern and the moment of ovulation in ewes.

\section{Acknowledgements}

Authors acknowledge Dr. Carlos Mantero, Director of the Estación Experimental Bernardo Rossengurtt for the facilities for performing this study, and Tec. Pec. Ignacio Sosa, Nicolas Zunino, Maria Jesús Frisch, Monserrat Costa, Belen Gomez, Laura Blanco and Rodrigo Dematté for their help with animal management. The Comisión Sectorial de Investigación Científica (CSIC, Universidad de la República) supported a study visit from JB to the Universidad Austral (Chile) to measure LH and $17 \beta$-estradiol. Authors give special thanks to Dr. Cesar Ulloa and Dr. Albert Carrasco who collaborated in the measurements of hormones. JB has a postgraduate scholarship from the Agencia Nacional de Investigación e Innovación (ANII, Uruguay). MGKR participated in this study during a study visit supported by Coordenação de Aperfeiçoamento 
de Pessoal de Nível Superior - Brasil (CAPES) - Finance Code 001 as part of her doctoral program (PDSE).

\section{References}

Alexander SL, Irvine CHG, Shand N, Evans MJ. Is luteinizing hormone secretion modulated by endogenous oxytocin in the mare? Studies on the role of oxytocin and factors affecting its secretion in estrous mares. Biol Reprod. 1995;1(monograph_series1):177-87.

http://dx.doi.org/10.1093/biolreprod/52.monograph_series1.361.

Caraty A, Delaleu B, Chesneau D, Fabre-Nys C. Sequential role of E2 and GnRH for the expression of estrous behavior in ewes. Endocrinology. 2002;143(1):139-45. http://dx.doi.org/10.1210/endo.143.1.8605. PMid:11751602.

Clarke IJ. Induction of male behavior in ovariectomized ewes and ovariectomized-androgenized ewes chronically implanted with oestradiol-17ß or testosterone. Anim Reprod Sci. 1979;1(4):305-12. http://dx.doi.org/10.1016/0378-4320(79)90016-2.

Druart X, Rickard JP, Mactier S, Kohnke PL, Kershaw-Young CM, Bathgate R, Gibb Z, Crossett B, Tsikis G, Labas V, Harichaux G, Grupen CG, de Graaf SP. Proteomic characterization and cross species comparison of mammalian seminal plasma. J Proteomics. 2013;91:13-22. http://dx.doi.org/10.1016/j.jprot.2013.05.029. PMid:23748023.

Fletcher IC, Lindsay DR. Effect of rams on the duration of oestrus behaviour in ewes. J Reprod Fertil. 1971;25(2):253-9. http://dx.doi.org/10.1530/jrf.0.0250253. PMid:5105152.

Fulkerson WJ, Adams NR, Gherardi PB. Ability of castrate male sheep treated with oestrogen or testosterone to induce and detect oestrus in ewes. Appl Anim Ethol. 1981;7(1):57-66. http://dx.doi.org/10.1016/0304-3762(81)90051-1.

Goodman RL, Gibson M, Skinner DC, Lehman MN. Neuroendocrine control of pulsatile GnRH secretion during the ovarian cycle: evidence from the ewe. Reprod Suppl. 2002;59:41-56. PMid:12698972.

Harper GP, Glanville RW, Thoenen H. The purification of nerve growth factor from bovine seminal plasma. Biochemical characterization and partial amino acid sequence. J Biol Chem. 1982;257(14):8541-8. http://dx.doi.org/10.1016/S0021-9258(18)34365-5. PMid:7085682.

Kendrick KM, Fabre-Nys C, Blache D, Goode JA, Broad KD. The role of oxytocin release in the mediobasal hypothalamus of the sheep in relation to female sexual receptivity. J Neuroendocrinol. 1993;5(1):1321. http://dx.doi.org/10.1111/j.1365-2826.1993.tb00359.x. PMid:8097940.

Kendrick KM, Keverne EV, Baldwin BA, Sharman DF. Cerebrospinal fluid levels of acetylcholinesterase, monoamines and oxytocin during labor, parturition, vaginocervical stimulation, lamb separation and suckling in sheep. Neuroendocrinology. 1986;44(2):149-56. http://dx.doi.org/10.1159/000124638. PMid:3796790.

Kershaw-Young CM, Druart X, Vaughan J, Maxwell WM. $\beta$-Nerve growth factor is a major component of alpaca seminal plasma and induces ovulation in female alpacas. Reprod Fertil Dev. 2012;24(8):10937. http://dx.doi.org/10.1071/RD12039. PMid:22951217.

Lindsay DR, Cognie Y, Pelletier J, Signoret JP. Influence of the presence of rams on the timing of ovulation and discharge of LH in ewes. Physiol Behav. 1975;15(5):423-6. http://dx.doi.org/10.1016/00319384(75)90208-5. PMid:1241139.

Marion GB, Smith VR, Wiley TE, Barret GR. The effect of sterile copulation on the time of ovulation in dairy heifers. J Dairy Sci. 1950;33(12):885-9. http://dx.doi.org/10.3168/jds.S0022-0302(50)91985-0.

O'Byrne KT, Lunn SF, Coen SW. Central oxytocin stimulates luteinizing hormone release in the marmoset, a primate which fails to show lactationally-induced infertility. J Neuroendocrinol. 1990;2(4):419-21. http://dx.doi.org/10.1111/j.1365-2826.1990.tb00426.x. PMid:19215367.

Parker GA, Birkhead TR. Polyandry: the history of a revolution. Philos Trans R Soc Lond B Biol Sci. 2013;368(1613):20120335. http://dx.doi.org/10.1098/rstb.2012.0335. PMid:23339245.

Preston BT, Stevenson IR, Pemberton JM, Wilson K. Dominant rams lose out by sperm depletion. Nature. 2001;409(6821):681-2. http://dx.doi.org/10.1038/35055617. PMid:11217847.

Randel RD, Short RE, Christensen DS, Bellows RA. Effects of various mating stimuli on the LH surge and ovulation time following synchronization of estrus in the bovine. J Anim Sci. 1973;37(1):128-30. http://dx.doi.org/10.2527/jas1973.371128x. PMid:4737208. 
Ratto MH, Leduc YA, Valderrama XP, van Straaten KE, Delbaere LTJ, Pierson RA, Adams GP. The nerve of ovulation-inducing factor in semen. Proc Natl Acad Sci USA. 2012;109(37):15042-7. http://dx.doi.org/10.1073/pnas.1206273109. PMid:22908303.

Recabarren SE, Escobar H, Lobos A, Recabarren MP, Parilo J. Luteinizing hormone pulse frequency is increase by arginine infusion in prepubertal sheep. Exp Clin Endocrinol Diabetes. 1996;104(1):72-7. http://dx.doi.org/10.1055/s-0029-1211425. PMid:8750574.

Roelofs JB, Bouwman EG, Dieleman SJ, Van Eerdenburg FJCM, Kaal-Lansbergen LMTE. Influence of repeated rectal ultrasound examinations on hormone profiles and behaviour around oestrus and ovulation in dairy cattle. Theriogenology. 2004;62(7):1337-52. http://dx.doi.org/10.1016/j.theriogenology.2004.02.002. PMid:15325559.

Romano JE, Abella DF. Effect of servcie on duration of oestrus and ovulation in dairy goats. Anim Reprod Sci. 1997;47(1-2):107-12. http://dx.doi.org/10.1016/S0378-4320(96)01633-8. PMid:9233510.

Romano JE, Alkar A, Amstalden M. Effect of copulation on estrus duration and ovulation time in goats. Theriogenology. 2016;85(2):330-4. http://dx.doi.org/10.1016/j.theriogenology.2015.09.021. PMid:26483310.

Romano JE, Benech A. Effect of service and vaginal-cervical anesthesia on estrus duration in dairy goats. Theriogenology. 1996;45(3):691-6. http://dx.doi.org/10.1016/0093-691X(95)00415-5. PMid:16727831.

Romano JE, Keisler DH, Amstalden M. Effect of copulation on estrus duration, LH response, and ovulation in Boer goats. Theriogenology. 2018;121:62-6. http://dx.doi.org/10.1016/j.theriogenology.2018.07.018. PMid:30138795.

Romano JE. Effect of service number on estrus duration in dairy goats. Theriogenology. 1994a;41(6):1273-7. http://dx.doi.org/10.1016/0093-691X(94)90485-2. PMid:16727481.

Romano JE. Effects of different stimuli of service on estrus duration in dairy goats. Theriogenology. 1994b;42(5):875-9. http://dx.doi.org/10.1016/0093-691X(94)90455-R. PMid:16727592.

Shibusawa K, Saito S, Fukuda M, Kawai T, Yamada H, Tomizawa K. Neurosecretion of oxytocin stimulates the reléase of the pituitary gonadotrophin. Endocrinol Jpn. 1955;2(3):183-7. http://dx.doi.org/10.1507/endocrj1954.2.183. PMid:13285433.

Signoret JP, Buisson FM, Mauléon P. Effect of mating on the onset and duration of ovulation in the sow. J Reprod Fertil. 1972;31(2):327-30. http://dx.doi.org/10.1530/jrf.0.0310327. PMid:4674007.

Tilbrook AJ, Cameron AWN. The contribution of the sexual behavior of rams to successful mating of ewes under field conditions. In: Oldham CM, Martin GB, Purvis IW, editors. Reproductive physiology of Merino sheep: concepts 30 and consequences. Crawley: The University of Western Australia; 1990. p. 143-60.

Tilbrook AJ, Lindsay DR. Differences in the sexual "attractiveness" of oestrous ewes to rams. Appl Anim Behav Sci. 1987;17(1-2):129-38. http://dx.doi.org/10.1016/0168-1591(87)90015-3.

Tilbrook AJ, Pearce DT. Pattern of loss of spermatozoa from the vagina of the ewe. Aust J Biol Sci. 1986;39(3):295-303. http://dx.doi.org/10.1071/BI9860295. PMid:3827743.

Ungerfeld R, Lacuesta L. Competition between different social ranked-rams has similar effects on testosterone and sexual behavior throughout the year. Reprod Domest Anim. 2015;50(6):1022-7. http://dx.doi.org/10.1111/rda.12630. PMid:26489705.

Ungerfeld R, Rubianes E. Estrus response to the ram effect in Corriedale ewes primed with medroxyprogesterone during the breeding season. Small Rumin Res. 1999;32(1):89-91. http://dx.doi.org/10.1016/S0921-4488(98)00164-3.

Waberski D, Südhoff H, Hahn T, Jungblut PW, Kallweit E, Calvete J, Ensslin M, Hoppen HO, Wintergalen N Weitze KF, Topfer-Petersen E. Advanced ovulation in gilts by the intrauterine application of a low molecular mass pronase-sensitive fraction of boar seminal plasma. J Reprod Fertil. 1995;105(2):24752. http://dx.doi.org/10.1530/jrf.0.1050247. PMid:8568767.

Wheeler AG, Baird DT, Land RB, Scaramuzzi RJ. Increased secretion of progesterone from the ovary of the ewe during the preovulatory period. J Reprod Fertil. 1975;45(3):519-22. http://dx.doi.org/10.1530/jrf.0.0450519. PMid:1239511.

\section{Author contributions}

JPB: Conceptualization, Methodology, Data curation, Writing the original draft; RPC: Methodology, Data curation, Writing- review and editing; MGKR: Methodology, Data curation, Writing - review and editing; MR: Conceptualization, Methodology, Data curation, Writing - review and editing; RU: Conceptualization, Methodology, Formal analysis, Writing - review and editing. 